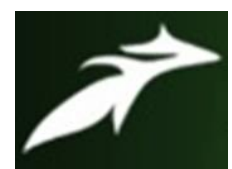

Subrat Kumar Maharana et al, Int. Journal of Advances in Agricultural Science \& Technology,

Vol.8 Issue.10, October-2021, pg. 1-6

\title{
CONSTRAINTS FACED BY WOMEN INVOLVED IN SELF-HELP GROUPS AND SEEK THEIR SUGGESTIONS FOR BETTER INVOLVEMENT
}

\author{
Subrat Kumar Maharana* \\ M.Sc. Ag. (Agricultural Extension and Communication), SHUATS \\ Prof. (Dr.) Ms. Jahanara** \\ Professor \& Head, Department of Agricultural Extension and Communication, SHUATS \\ Dr. Dipak Kumar Bose**** \\ Associate Professor, Department of Agricultural Extension and Communication, SHUATS
}

DOI: 10.47856/ijaast.2021.v08i10.001

Abstract: A SHG is a small economically homogeneous affinity group of the rural poor voluntarily coming together to save small amount regularly, which are deposited in a common fund to meet members emergency needs and to provide collateral free loans decided by the group. The present study was conducted in Koksara block of Kalahandi district of Odisha. Ex-post facto research design was followed for the present study. The data was collected from 150 respondents. It was collected randomly from 10 villages using pretested structured interview schedule and analyzed using frequency, percentage \& Ranking. From the data collection it was found that majority of respondents were facing major constraints such as loans were not sufficient followed by lack of knowledge and skills and so on. Suggestions offered by them were such as Women must be literate; there should be Family support for business \& easy bank loan procedure and so on.

Keywords: SHG Empowerment, Knowledge, Skills, Constraints, etc. 


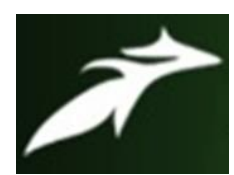

Subrat Kumar Maharana et al, Int. Journal of Advances in Agricultural Science \& Technology,

Vol.8 Issue.10, October-2021, pg. 1-6

ISSN: 2348-1358

Impact Factor: 6.057

NAAS Rating: 3.77

\section{Introduction}

Self-help Groups (SHGs) are playing a major role in removing poverty in the rural India today. The group-based model of self-help is widely practiced for rural development, poverty alleviation and empowerment of women. Self-help as a strategy for social development places emphasis on self-reliance, human agency and action. It aims to mobilize people, to give them voice and build people's organizations that will overcome barriers to participation and empowerment. Central to the idea of self-help is the formation of groups, concept of a community and the development of egalitarian relationships that will promote people's wellbeing. Self Help Groups serve as a medium of delivering micro credit to the members. (Heggani, 2014)

A SHG is a small economically homogeneous affinity group of the rural poor voluntarily coming together to save small amount regularly, which are deposited in a common fund to meet members emergency needs and to provide collateral free loans decided by the group. They have been recognized as useful tool to help the poor and as an alternative mechanism to meet the urgent credit needs of poor through thrift. SHGs enhance the equality of status of women as participants, decision-makers and beneficiaries in the democratic, economic, social and cultural spheres of life (Ritu Jain, 2003)

The basic principles of the SHGs are group approach, mutual trust, organization of small and manageable groups, group cohesiveness, sprit of thrift, demand based lending, collateral free, women friendly loan, peer group pressure in repayment, skill training capacity building and empowerment. (Sindhe, 2014)

National bank for agriculture and rural development with its vision for the development of rural areas started the self-help group linkage in 1992. The aim of the self-help group bank linkage Programme was to combine the elements of adjustability, adaptability and sensibility of the informal credit system and the elements like organizational and managerial excellence, financial stability such that there would be a credit system tailor-made for rural India. The Programme would create an interface between the formal banking system and the rural poor. Widening the credit system such that it reaches the grass root level where it is not accessible. 


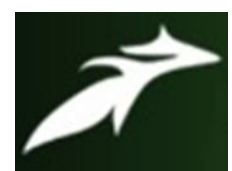

Subrat Kumar Maharana et al, Int. Journal of Advances in Agricultural Science \& Technology, Vol.8 Issue.10, October-2021, pg. 1-6

ISSN: 2348-1358

Impact Factor: 6.057

NAAS Rating: 3.77

The self-help group bank linkage Programme has three models which are used in the linkage of rural poor to the formal banking system.(Singh, 2017)

\section{Research Methodology}

Ex-post facto research design was followed for the present study. Koksara block of Kalahandi district of Odisha was selected by purposive sampling for the present study. Total 10 number of villages were selected by random sampling. Total 150 number of respondents were selected for the present study. The data was collected by using the pre structured interview schedule. Data analysis is done through frequency, percentage and Rank distribution using statistical tools.

For calculating percentage, frequency was multiplied by 100 and divided by total number of respondents.

$\mathrm{P}=\mathrm{X} / \mathrm{N} \times 100$

Where, $\mathrm{P}=$ Percentage

$\mathrm{X}=$ Frequency of the respondents

$\mathrm{N}=$ Total number of respondents

\section{Results and Discussion}

Table 1: Distribution of respondents according to their Constraints faced by respondents in Self-help groups.

\begin{tabular}{|l|c|c|c|}
\hline S. No. & \multicolumn{2}{|c|}{ Constraints } & \multicolumn{2}{|c|}{ Response } \\
\cline { 3 - 4 } & & Frequency (\%) & Rank \\
\hline $\mathbf{1 .}$ & Income derived is too little & $103(68.66)$ & IV $^{\text {th }}$ rank \\
\hline $\mathbf{2 .}$ & Frequent training should be imparted & $109(72.66)$ & III $^{\text {rd }}$ rank \\
\hline
\end{tabular}




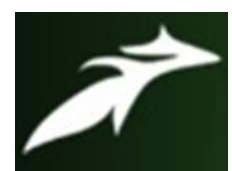

Subrat Kumar Maharana et al, Int. Journal of Advances in Agricultural Science \& Technology,

Vol.8 Issue.10, October-2021, pg. 1-6

ISSN: 2348-1358

Impact Factor: 6.057

NAAS Rating: 3.77

\begin{tabular}{|c|c|c|c|}
\hline 3. & Lack of knowledge and skills & $111(74.00)$ & II $^{\text {nd }}$ rank \\
\hline 4. & Non availability of resources & $78(52.00)$ & $\mathrm{X}^{\text {th }}$ rank \\
\hline $\mathbf{5 .}$ & Lack of markets and marketing information & $98(65.33)$ & VI $^{\text {th }}$ rank \\
\hline 6. & Lack of social mobility & $87(58.00)$ & VII $^{\text {th }}$ rank \\
\hline 7. & Family restriction & $85(56.66)$ & VIII $^{\text {th }}$ rank \\
\hline $\mathbf{8 .}$ & Loans are not sufficient & $127(84.66)$ & I $^{\text {st }}$ rank \\
\hline 9. & Lack of training & $101(67.33)$ & V $^{\text {th }}$ rank \\
\hline $\mathbf{1 0 .}$ & Lack of education & $82(54.66)$ & IX $^{\text {th }}$ rank \\
\hline
\end{tabular}

From the above table it is revealed that the constraints faced by the respondents. The topranking constraint was loans were not sufficient which consists around 84.66 per cent (I ${ }^{\text {st }}$ rank) followed by lack of knowledge and skills which consists around 74.00 per cent (II ${ }^{\text {nd }}$ rank), Frequent training should be imparted which consists around 72.66 per cent (III ${ }^{\text {rd }}$ rank), Income derived is too little which consists around 68.66 per cent (IV ${ }^{\text {th }}$ rank), lack of training which consists round 67.33 per cent $\left(\mathrm{V}^{\text {th }}\right.$ rank), Lack of markets and marketing information which consists around 65.33 per cent (VI ${ }^{\text {th }}$ rank), Lack of social mobility which consists around 58.00 per cent (VII ${ }^{\text {th }}$ rank), family restrictions which consists around 56.66 per cent (VIII ${ }^{\text {th }}$ rank), lack of education which consists around 54.66 per cent (IX ${ }^{\text {th }}$ rank) and Non availability of resources which consists around 52.00 per cent ( $\mathrm{X}^{\text {th }}$ rank). 


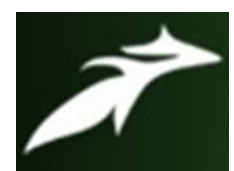

Subrat Kumar Maharana et al, Int. Journal of Advances in Agricultural Science \& Technology,

Vol.8 Issue.10, October-2021, pg. 1-6

ISSN: 2348-1358

Impact Factor: 6.057

NAAS Rating: 3.77

\section{Suggestions offered by respondents for better involvement in SHG listed below:}

Dependency in decision making

Women must be literate

$>$ intervention of male, should not be in rural women SHG

Member should have equal economic status

Easy bank loan procedure

Confidence building

Coordination is must, among the members

$>$ Group numbers should have common needs and object

Family support for business.

\section{Conclusion}

It is concluded that Self-help Groups (SHGs) are playing a major role in removing poverty in the rural India today. The group-based model of self-help is widely practiced for rural development, poverty alleviation and empowerment of women. The top-ranking constraint was loans were not sufficient, lack of knowledge and skills, Frequent training, Income derived is too little, lack of training, Lack of markets and marketing information, Lack of social mobility, family restrictions, lack of education and non-availability of resources. Suggestions offered by respondents for better involvement in SHG such as Women must be literate, there should be Family support for business \& easy bank loan procedure and so on. 


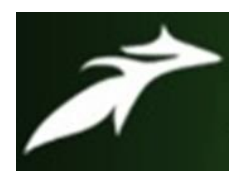

Subrat Kumar Maharana et al, Int. Journal of Advances in Agricultural Science \& Technology, Vol.8 Issue.10, October-2021, pg. 1-6

ISSN: 2348-1358

Impact Factor: 6.057

NAAS Rating: 3.77

\section{References}

[1]. Singh, U. B. and Gupta, T. (2017) Does SHG - Bank Linkage Programme Lead to the Women Empowerment, International Journal of Scientific and Research Publications, Vol. 7, Issue. 7, ISSN 2250-3153.

[2]. Heggani, J. K. and Sindhe, J. R. (2014) Women Empowerment Through Self-Help Groups: A Review of Literature, Indian Journal of Applied Research, Vol. 4, Issue. 10, ISSN - 2249-555X.

[3]. Jain, R. (2003): Socio-Economics Impact Through Self Help Groups. Yojana. Vol. 47. No.7. July 2003. P.11-12. 